\title{
Media Pembelajaran Berbasis Audio Visual Ayo Belajar Budaya Nusantara untuk Menstimulasi Perkembangan Bahasa Anak Usia Dini
}

\section{Ni Made Indah Kusuma Sari 1*}

${ }_{1}^{1}$ Prodi Pendidikan Guru Pendidikan Anak Usia Dini, Universitas Pendidikan Ganesha, Singaraja, Indonesia

\section{ART I C LE I N F O}

Article history:

Received July 31, 2021

Revised July 31, 2021

Accepted October 23, 2021

Available online December 25, 2021

Kata Kunci:

Audio Visual, Budaya Nusantara,

Media Pembelajaran,

Perkembangan Bahasa, Model ADDIE

\section{Keywords:}

Audio-Visual, Archipelago Culture,

Learning Media, Language

Development, ADDIE Model

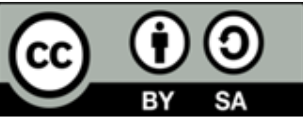

TThis is an open access article under the CC BY-SA license.

Copyright (C) 2021 by Author. Published by Universitas Pendidikan Ganesha.

\begin{abstract}
A B S T R A K
Mengingat kurangnya penggunaan media pembelajaran berbasis audio visual yang efektif untuk menstimulus perkembangan bahasa pada anak dan memberikan anak kesempatan untuk mengkreasi pada piranti handphone serta anak masih berpatokan pada hasil karya guru dan temannya. Berdasarkan hal tersebut penelitian ini bertujuan untuk menghasilkan media pembelajaran berbasis audio visual mengenai ayo belajar budaya nusantara untuk menstimulasi perkembangan bahasa pada anak kelompok B. Subjek uji coba penelitian ini terdiri atas 1 orang uji ahli isi materi, 1 orang uji ahli desain dan media pembelajaran dan 3 orang anak kelompok $\mathrm{B}$. Penelitian pengembangan ini menggunakan model ADDIE. Metode pengambilan data dilakukan dengan metode observasi, wawancara, dan kusioner/angket.Instrument pengumpulan data menggunakan lembar observasi, wawancara dan kuesioner/angket. Hasil validitas dari produk yang dikembangkan yaitu hasil ahli isi materi sebesar $82 \%$ tergolong kualifikasi sangat baik, hasil ahli desain media pembelajaran sebesar $95 \%$ tergolong kualifikasi sangat baik, hasil ahli media pembelajaran sebesar $85 \%$ tergolong kualifikasi sangat baik dan hasil uji coba perorangan sebesar $88 \%$ tergolong kualifikasi sangat baik sehingga media dinyatakan layak dan valid digunakan dalam pembelajaran. Media pembelajaran ini memiliki tampilan yang menarik sesuai untuk mengenal budaya nusantara, sehingga mampu membuat anak senang dan memotivasi anak dalan memahami pembelajaran yang diberikan. Media pembelajaran ini juga memotivasi guru dalam mengasah kemampuannya dalam memanfaatkan kemajuan teknologi.
\end{abstract}

\section{A BS TRACT}

Given the lack of effective audio-visual-based learning media to stimulate language development in children and give children the opportunity to be creative on mobile devices, children still rely on the work of teachers and friends. This study aims to produce audio-visual-based learning media that let us learn Indonesian culture to stimulate language development in group $B$ children. The trial subjects of this study consisted of 1 person testing material content expert, 1 person testing design and learning media experts, and 3 children in group B. This development research uses the ADDIE model. The method of data collection was carried out by observation, interviews, and questionnaires/questionnaires. The data collection instrument used observation sheets, interviews, and questionnaires/questionnaires. The results of the validity of the developed product are the results of material content experts of $82 \%$ classified as very good qualifications. The results of learning media design experts by $95 \%$ belonging to very good qualifications, the results of learning media experts by $85 \%$ belonging to very good qualifications and the results of individual trials of $88 \%$ is classified as very good qualification so that the media is declared feasible and valid to be used in learning. This learning media has an attractive appearance suitable for getting to know the culture of the archipelago so that it can make children happy and motivate children to understand the learning given. This learning media also motivates teachers to hone their abilities in utilizing technological advances. 


\section{PENDAHULUAN}

Pendidikan khususnya pada anak usia dini merupakan salah satu upaya yang dapat menstimulasi perkembangan dan pertumbuhan anak sejak dini, agar tercapainya aspek perkembangan anak sebelum menempuh pendidikan kejenjang yang lebih tinggi. Pada usia dini sangat penting bagi anak untuk dikenalkan kecintaan terhadap tanah air salah satunya yaitu pendidikan multikultural. Pendidikan multicultural diangga $\mathrm{p}$ dapat meningkatkan kesadaran positif tentang pengetahuan keberagaman baik keberagaman suku maupun budaya, seperti saat anak mengenal identitas sukunya dan suku temennya anak dapat menyikapi hal tersebut secara positif (Najmina, 2018). Hal ini sudah sesuai dengan makna pendidikan yang memiliki tujuan untuk mewariskan nilai-nilai kebudayaan pada anak usia dini agar dapat menumbuhkan wawasan dan kesadaran cinta tanah air yang berlandaskan kebudayaan (Tuasikal, 2021). Pendidikan yang berkualitas akan memberikan dampak yang positif terhadap perkembangan anak. Perkembangan pada anak terutama anak usia dini mencakup 6 aspek perkembangan yaitu Perkembangan Nilai Agama dan Moral, Perkembangan Kognitif, Perkembangan Bahasa, Perkembangan Fisik Motorik, Perkembangan Sosial Emosional dan Perkembnagan Seni (Fatihakun \& Suryadilaga, 2021). Anak usia dini ialah anak yang sedang mengalami masa perkembangan dimulai dari usia 0 sampai 8 tahun, dimana dalam masa ini sangat tepat untuk anak mengembangkan segala potensi yang dimilikinya. Potensi dalam diri anak hanya akan berkembang apabila adanya stimulus yang sesuai untuk pertumbuhannya. Hal ini sudah pasti tidak terlepas dari peran pendidik sebagai fasilitator dalam memberikan pendidikan pada anak.Pendikan anak usia dini sangat penting untuk diperhatikan khususnya di taman kanak-kanak. Taman kanak-kanak merupakan bentuk pendidikan formal yang memberi fasilitas bagi perkembangan anak untuk membantu pertumbuhan dan perkembangannya (Zeptyani \& Wiarta, 2020).

Pada anak usia dini, perkembangan bahasa menjadi salah satu hal yang penting untuk dikembangkan, selain itu perkembangan bahasa merupakan hal dasar yang seharusnya dapat dikembangkan, karena aspek bahasa memungkinkan anak untuk dapat berkomunikasi dan berinteraksi dengan orang lain disekitarnya. Anak usia dini memerlukan pendidikan yang sangat fundamental dan perlu mendapat perhatian yang memadai dari keluarga, masyarakat dan negara, karena pendidikan anak di jenjang berikutnya sangat dipengaruhi, bahkan ditentukan oleh berbagai stimulasi bermakna yang diberikan sejak usia dini (Cahya Ningrum et al., 2020; Subandji et al., 2020). Stimulus yang diberikan pada anak sudah dimulai dari tahap prenatal (dalam kandungan) untuk melakukan interaksi dengan orang tua dengan menggunakan media yang tepat saat pemberian stimulus sehingga akan mencapai hasil yang optimal (Fatihakun et al., 2021). Pemberian stimulus pada anak sejak dini sangatlah penting untuk menunjang aspek perkembangan pada anak.Bahasa adalah pikiran, ucapan, dan perasaan seseorang sebagai alat komunikasi antar anggota masyarakat yang terdiri dari, menyimak, berbicara, membaca, dan menulis (Anggraini et al., 2019). Selain itu, bahasa merupakan suatu kegiatan dimana anak dapat berekspresi mengenai perasaan, ide maupun pikirannya. Jadi dari uraian di atas disimpulkan bahwa perkembangan bahasa pada anak akan berkembang dengan baik apabila mendapatkan stimulus yang tepat, sehingga anak dapat berkomunikasi dengan lingkungan sekitarnya.

Pada abad ke-21 ini sudah banyak teknologi yang dapat membantu dalam melatih 6 aspek perkembangan yang ada pada anak terutama anak usia dini. Perkembangan aplikasi multimedia yang semakin cepat dan populer di masyarakat, terutama dikalangan anak - anak dapat membantu daya pikir anak.Kurangnya keaktifan siswa dalam belajar niscaya dapat mengerdilkan potensi berpikirnya, sehingga perkembangan bahasa pada anak menjadi lemah dalam pertumbuhannya. Padahal, perkembangan bahasa pada anak sangat dibutuhkan dalam menghadapi tantangan abad 21 (Santyasa et al., 2018). Multimedia bisa diartikan sebagai bentuk kombinasi antara teks, grafik, animasi, suara dan gambar dimana media ini ditekankan kepada kendali komputer sebagai penggerak keseluruhan gabungan media ini (Pradnyana et al., 2020). Dengan demikian arti multimedia yang umumnya dikenal dewasa ini adalah berbagai macam kombinasi grafik, teks, suara, video, dan animasi.Karena semakin menariknya aplikasi multimedia maka peneliti ingin membuat suatu aplikasi multimedia interaktif yang dapat memberikan pengaruh besar dalam dunia pendidikan.Berdasarkan hasil observasi dan wawancara yang dilaksanakan di TK Tunas Cempakaditemukan bebebrapa masalah, yaitu rendahnya perkembangan bahasa pada anak. Akabit dari masa pandemi covid-19 semua guru harus melaksanakan proses pembelajaran jarak jauh, maka diperlukan media pembelajaran pendukung dalam melaksanakan proses belajar mengajar yang efektif. Selain itu, dimasa sekarang ternyata masih banyak guru yang masih belum bisa memanfaatkan alat elektronik seperti komputer, laptop dan HP android dengan semaksimal mungkin. Hal ini menyebabkan anak cenderung bersikap pasif dalam proses pembelajaran, sehingga hanya sebagai penerima informasi dari guru. Teknik pembelajaran yang hanya memberikan berupa penugasan melalui pesan atau video melalui WhatsApp menyebabkan dalam proses pembelajaran anak kurang mendapat kesempatan secara luas untuk menyampaikan ide-ide atau gagasan, mengembangkan pengalaman, dan potensi yang dimiliki, sehingga menyebabkan turunnya motivasi dan minat belajar. Maka dari itu dipandang perlu mengembangkan media 
pembelajaran untuk membantu guru dalam menyampaikan materi pelajaran perkembangan bahasa pada anak usia dini. Media pembelajaran sebagai perantara guru dan anak serta memudahkan guru dalam menyampaikan materi pembelajaran.Selain itu melalui media pembelajaran guru terbantu dalam penyampaian materi pelajaran kepada anak (Darmayanti et al., 2017; Maqfiroh et al., 2020). Media pembelajaran dapat mengaktifkan dan memotivasi siswa dalam belajar dan media pembelajaran sebagai alat bantu kegiatan belajar mengajar untuk menyampaikan pesan agar mudah diterima (Syukur \& Fallo, 2019; Yuangga \& Sunarsi, 2020). Salah satu media yang digunakan adalah media audio visual. Media pembelajaran yang dikembangkan berbasis audio visual dengan materi budaya nusantara.Media audio visual mampu meningkatkan prestasi belajar siswa (Patmawati et al., 2018). Media pembelajaran digital berbasis audio visual menjadi langkah strategis untuk memberikan pengalaman baru pembelajaran (Setiawan et al., 2019; Susila et al., 2018). Audio visual mampu menstimulasi perkembangan bahasa bagi anak usia dini (Fatmawati et al., 2021). Oleh karena itu tujuan penelitian ini adalah mengembangkan media pembelajaran audio visual untuk menstimulasi perkembangan bahasa pada anak usia dini dan membantu guru dalam menyampaikan materi pembelajaran agar tidak monoton dan membosankan dengan menggunakan animasi yang menarik.

\section{METODE}

Model penelitian pengembangan yang penulis gunakan adalah model ADDIE(Analysis, Design, Development, Implementation, Evaluations). Model ini sering digunakan untuk menggambarkan pendekatan sistematis untuk pengembangan instruksional. Penelitian pengembangan ini mengembangkan media pembelajaran berbasis audio visual mengenai ayo belajar budaya nusantara untuk menstimulasi perkembangan bahasa pada anak usia dini pada Kelompok B TK Tunas Cempaka. Tahap analisis adalah tahap untuk mengumpulkan informasi, pengumpulan informasi pada tahap ini dilakukan dengan cara observasi lapangan ke TK dan wawancara dengan guru TK. Kegiatan dijadikan sebagai acuan untuk mengembangkan produk yang sesuai dengan kebutuhan dan hasil observasi dengan pihak sekolah, dalam hal ini produk yang dikembangkan adalah media pembelajaran ayo belajar budaya nusantara.Dalam tahap analisis dilakukan analisis kesenjangan, analisis kebutuhan di lapangan dan analisis kompetensi dasar dan indicator. Tahap desain dilakukan untuk mempermudah peneliti dalam merancang gambaran mengenai isi dan tampilan dari media pembelajaran berbasis audio visual mengenai ayo belajar budaya nusantara ini. Tahap desain meliputi tahap pengumpulan data, menyusun bagan alur (flowcart) dan sketsa (storyboard). Tahap pengembangan adalah tahap mengembangkan media pembeljaran berdasarkan rancangan media awal. Adapun tahap-tahap yang dilakukan dalam mengembangkan media pembelajaran berbasis audio visual mengenai ayo belajar budaya nusantara yaitu : a) Melakukan pembuatan media pembelajaran berbasis audio visual mengenai ayo belajar budaya nusnatara. Pembuatan media pembelajaran berbasis audio visual mengani ayo belajar budaya nusantara dilihat dari segi desain dan segi materi yang nantinya akan terlihat perbedaan dengan media pembelajaran yang digunakan di sekolah. b) Melakukan review media pembelajaran dengan memvalidasikan media pembelajaran oleh ahli desain, ahli media dan ahli isi materi. c) Memperbaiki media pembelajaran sesuai dengan saran dan masukan dari ahli desain, ahli media dan ahli isi pembelajaran sehingga terdapat perbandingan dari media awal dan media setelah revisi.Tahap implementasi yaitu tahap melakukan implementasi media pembelajaran dalam proses pembelajaran. Tahap imlementasi ini bertujuan untuk mengetahui respon anak terhadap media pembelajaran berbasis audio visual mengenai ayo belajar budaya nusantara. Implementasi penggunaan media ini hanya dilakukan pada uji coba perorangan dikarenakan saat ini kondisi pandemi Covid-19, anak-anak bejar dari rumah secara daring. Tahap evaluasiuntuk menilai kualitas prosedur dan hasil pembelajaran ketika diterapkan maupun sesudah penerapan dan menganalisis data yang diperoleh dari peserta didik untuk mengetahui pendapat atau respon mengenai produk yang telah dibuat.Pada tahap ini dilakukan validitas untuk mengetahui kelayakan media audio visual pembelajaran yaitu uji ahli materi, uji ahli media dan uji ahli desain. Selain itu juga dilakukan uji respon siswa untuk mengetahui ketertarikan siswa terhadap media pembelajaran.

Jenis data yang peneliti gunakan dalam pengembangan media pembelajaran berbasis audio visual mengenai ayo belajar budaya nusantara untuk menstimulasi perkembangan bahasa pada anak kelompok B TK Tunas Cempaka ini berupa data kualitatif dan data kuantitatif.Dalam proses penelitian pengembangan ini metode pengumpulan data yang digunakan yaitu metode non tes. Metode non tes adalah cara penilaian hasil belajar anak yang dilakukan tanpa menguji anak melainkan dengan melakukan pengamatan sistematis. Dengan teknik non tes penilaian atau evaluasi hasil belajar anak dilakukan dengan pengamatan secara sistematis yaitu observasi, wawancara dan angket.Instrumen Pengumpulan Data pada penelitian ini berupa lembar angket validasi ahli isi materi, lembar angket validasi ahli desain, lembar angket validasi ahli media pembelajaran, dan angket tanggapan anak.Adapun kisi-kisi instrumen kuesioner validitas ahli pada 
media pembelajaran berbasis audiovisual mengenai ayo belajar budaya nusantara beserta kisi-kisi instrumen untuk uji efektivitas dapat dilihat pada Tabel 1, 2, 3 dan 4.

Tabel 1. Kisi-kisi Instrumen Review Ahli Isi Materi

\begin{tabular}{llll}
\hline No & Aspek & Komponen \\
\hline 1 & Kurikulum & 1) & Kesesuaian materi dengan kompetensi dasar \\
& & 2) & Kesesuaian materi dengan indikator pembelajaran \\
& & 3) & Kesesuaian materi dengan tujuan pembelajaran \\
& & 4) & Ketepatan materi \\
& 1) & Kemenarikan materi \\
& 2) & Ketermudahan anak dalam memamhami materi \\
& 3) & Kebermanfaatan materi bagi anak dalam kehidupan nyata \\
& 4) & Penggunaan bahasa yang tepat dan konsisten \\
& 5) & Kesesuaian evaluasi dengan materi \\
& 6) & Pemberian umpan balik hasil evaluasi materi \\
& 7) & Kemampuan media dalam membantu anak untuk menginat \\
& Media & 1) & Kengetahuan sebelumnya \\
& & 2) & Keterdukungan penggunaan media yang tepat bagi anak \\
\hline
\end{tabular}

Tabel 2. Kisi-kisi Instrumen Review Ahli Desain Pembelajaran

\begin{tabular}{clll}
\hline No & Aspek & & Komponen \\
\hline 1 & Tujuan & 1) & Kejelasan tujuan umum pembelajaran \\
& & 2) & Kesesuaian indikator pemebelajaran \\
& 3) & Kejelasan tujuan pembelajaran \\
2 & 1) & Penyampaian materi memberikan langkah-langkah yang logis dan alur \\
& & navigasi yang bebas \\
& & 2) & Membantu mengingat kemampuan dan pengetahuan sebelumnya \\
& 3) & Memberikan contoh-contoh dalam penyajiannya \\
& 4) & Penyampain materi yang menarik \\
& Evaluasi & 1) & Diberikan evaluasi untuk mengukur kemampuan anak \\
\hline
\end{tabular}

Tabel 3. Kisi-kisi Instrumen Review Ahli Media Pembelajaran

\begin{tabular}{lcll}
\hline No & Aspek & & Komponen \\
\hline 1 & Tampilan & 1) & Kemudahan penggunaan \\
& & 2) & Kualitas tampilan \\
& 3) & Konsistensi tombol \\
2 & Teks & 1) & Keterbacaan \\
3 & Gambar & 1) & Kesesuaian gambar \\
4 & Warna & 1) & Komposisi dan kombinasi warna yang tepat dan serasi \\
5 & Suara & 1) & Penggunaan musik yang sesuai \\
\hline
\end{tabular}

Tabel 4. Kisi-kisi Instrumen Uji Coba Perorangan

\begin{tabular}{llll}
\hline No & Aspek & Komponen \\
\hline 1 & Tampilan & 1) & Kemenarikan media pembelajaran \\
& & 2) & Kemudahan penggunaan media \\
2 & Teks & 1) & Keterbacaan teks \\
& & 2) & Penggunaan jenis huruf yang sesuai \\
& & 3) & Penggunaan ukuran huruf yang sesuai \\
3 & Gambar & 1) & Penggunaaan gambar yang sesuai dengan materi \\
4 & Motivasi & 1) & Media dapat membangkitkan motivasi anak \\
5 & Materi & 1) & Materi yang mudah dipahami \\
& & 2) & Tujuan pembelajaran mudah dipahami \\
6 & Evaluasi & 1) & Kesesuaian doal \\
& & 2) & Memberikan umpan balik hasil evaluasi \\
\hline
\end{tabular}


Teknik analisis data yang digunakan dalam mengembangkan media pembelajaran berbasis audio visual mengenai ayo belajar budaya nusantara adalla analisis deskriptif dengan hasil data berupa data kualitatif dan data kuantitatif. Dalam penelitian ini teknik analisis data deskriptif kualitatif, dilakukan dengan mengelompokkan hasil dari angket yang berupa masukan, tanggapan, kritik dan saran perbaikan dari para pakar ahli dan hasil wawancara dan observasi. Hasil analisis dari data yang didapat ini kemudian digunakan untuk merevisi produk yang dikembangkan. Analisis data deskriptif kuantitatif dilakukan dengan cara menganalisis data dari angket yang sebelumnya telah diberikan kepada responden yang terdiri atas ahli isi, ahli media dan ahli desain pembelajaran, serta hasil uji coba perorangan siswa Kelomok B TK Tunas Cempaka. Hasil analisis data kuantitatif berupa persentase kelayakan produk dan respon dari subyek penelitian, kemudian dianalisis menggunakan kriteria kelayakan media Ayo Belajar Budaya Nusantara, sehingga dapat diambil suatu keputusan mengenai layak atau tidaknya media aplikasi ini yang dikembangkan. Berikut dipaparkan mengenai analisis yang dilakukan terhadap angket dari responden penelitian. Analisis Kelayakan Media dari Ahli isi mata pelajaran, Ahli Media Pembelajaran dan Ahli Desain Pembelajaran dan uji coba perorangan. Jawaban yang terkumpul dari angket ahli media pembelajaran dan ahli isi dan ahli desain pembelajaran dianalisis menggunakan skala Likert yang telah dimodifikasi peneliti menjadi skala empat.

\section{HASIL DAN PEMBAHASAN}

\section{Hasil}

Adapun pengembangan media berbasis audio visual mengenai Ayo Belajar Budaya Nusantara ini dilakukan dengan menggunakan model ADDIE, yang terdiri atas tahap analisis, tahap desain, tahap pengembangan, tahap implementasi, dan tahap evaluasi. Rancang bangun pengembangan media berbasis audio visual mengenai Ayo Belajar Budaya Nusanatra ini mengacu pada materi budaya nusantara untuk menstimulus perkembangan bahasa pada anak usia dini. Pada media pembelajaran berbasis audio visual ini terdapat contoh-contoh budaya nusantara seperti pakaian adat dan rumah adat. Pengembangan media pembelajaran berbasis audio visual menggunakan adobe flash cs6.Tampilan pada media pembelajaran berbasis audio visual menggunakan pewarnaan, animasi dan gambar yang menarik sehingga mampu meningkatkan motivasi belajar anak. Tahap analisis ini menentukan tujuan dari pembelajaran, mengidentifikasi fasilitas pembelajaran yang ada di sekolah dan analisis kompetensi dasar dan indikator materi pada tahap menganalisis kebutuhan dilakukan melalui kegiatan observasi dan wawancara kepada guru kelompok B. kegiatan ini bertujuan agar mengetahui kebutuhan guru dan anak dalam kegiatan pembelajaran. Dari hasil observasi dan wawancara diketahui bahwa sangat diutuhkan media pembelajaran yang mendukung dalam upaya perkembangan bahasa pada anak juga bisa sekaligus mengenalkan rasa cinta tanah air sejak dini. Sehingga pada masa pandemi covid 19, guru melaksankan proses pembelajaran dari jarak jauh maka sangat dibutuhkan media pembelajaran yang mendukung dan efektif. Pengembangan media pembelajaran audio visual "ayo belajar budaya nusanatara" dalam upaya menstimulasi perkembangan bahasa pada anak kelompok B TK Tunas Cempaka diperoleh informasi sebagai berikut: guru merasa kesulitan dalam membuat media pembelajaran jarak jauh. Cara yang diterapkan guru kurang bervariatif. Guru hanya memanfaatkan aplikasiWhatsApp grup dalam proses pembelajaran sehingga sedikit membosankan.

Tahap perancangan kegiatan yang dilakukan yaitu mendesain produk yang sudah dibuat dalam bentuk flowchart dan storyboar sebagai dasar dan alur yang digunakan pada tahap pengembangan. Selain itu kegiatan yang dilakukan pada tahap ini yaitu memilih software yang cocok digunakan seperti bandicam, viva video, adobe flash CS6 atau adobe flash animate. Produk yang sudah dibuat dalam bentuk flowchart dan storyboardisajikan pada Gambar 1.Tahap pengembangan dilakukan pembuatan produk agar produk menjadi nyata sesuai dengan tahap perancangan yang sudah dilakukan. Setelah semua rancangan selesai dibuat selanjutnya dilakukan pengeditan menggunakan aplikasi Adobe Flash CS6. Pembuatan media pembelajaran ini awali dengan pembuatan backgroun, icon-icon gambar dan materi sesuai dengan media yang akan dikembangkan. Tahp selanjutnya menyatukan gambar dengan dubing, backsound, teks dan mengatur komposisi sesuai produk yang dikembangkan. Contoh Produk yang dikembangkan dapat disajikan pada Gambar 2 dan 3.

Pada tahap validitas media pembelajaran audio visual "ayo belajar budaya nusantara" di review oleh para ahli isi, ahli media, ahli desain pembelajaran, uji coba perorangan. Instrument yang digunakan untuk mengetahui validitas produk yang sudah dikembangkan yaitu berupa angket. Berdasarkan hasil review oleh ahli materi diperoleh validasi sebesar $82 \%$ berada pada rentangan $76-100 \%$ dengan kualifikasi "sangat baik". Namun ada beberapa masukan dan saran oleh ahli materi guna menyempurnakan media pembelajaran berbasis audio visual. Adapun saran dari ahli materi yaitu unsur kebahasaan yaitu redaksional pada instrumen di poin 2,4,6 dan 7 kurang tepat. Selanjutnya validasi oleh ahli media untuk 
menilai tampilan, gambar, warna, teks pada media pembelajaran berbasis audio visual. Melaui penilaian ahli media diperoleh nilai sebesar $85 \%$ berada pada kategori sangat baik, dapat dilihat melalui kualifikasi dengan Tabel konversi sehingga desain pembelajaran media pembelajaran berbasis audio visual mengenai ayo belajar budaya nusantara ini tidak perlu revisi. Selanjutnya dilakukan validasi ahli desain pembelajaran. Berdasarkan hasil penilaian maka diperoleh presentasesebesar 95\% berada pada kategori sangat baik dilihat dari kualifikasi dengan Tabel konversi.Jadi media pembelajaran berbasis audio visual layak untuk digunakan berdasarkan validasi oleh ahli materi pembelajaran, ahli media pembelajaran dan ahli desain pembelajaran.Dengan demikian media pembelajaran berbasis audio visual mengenai ayo belajar budaya nusantara memiliki peran yang sangat baik dan layak untuk digunakan dalam menstimulus perkembangan bahasa pada anak pada saat kegiatan pembelajaran. Setelah melalui tahapan pengujian/review dari para ahli, selanjutnya dilakukan uji coba perorangan. Uji coba perorangan dilaksanakan setelah tahap review ahli. Pada tahap uji coba perorangan ini dilakukan oleh tiga orang anak kelompok B TK Tunas Cempaka. Tiga anak ini masing-masing memiliki kemapuan yang berbeda dalam menyerap pembelajaran ada yang cepat, sedang dan lamban. Hasil uji perorangan dijabarkan pada Tabel 5.
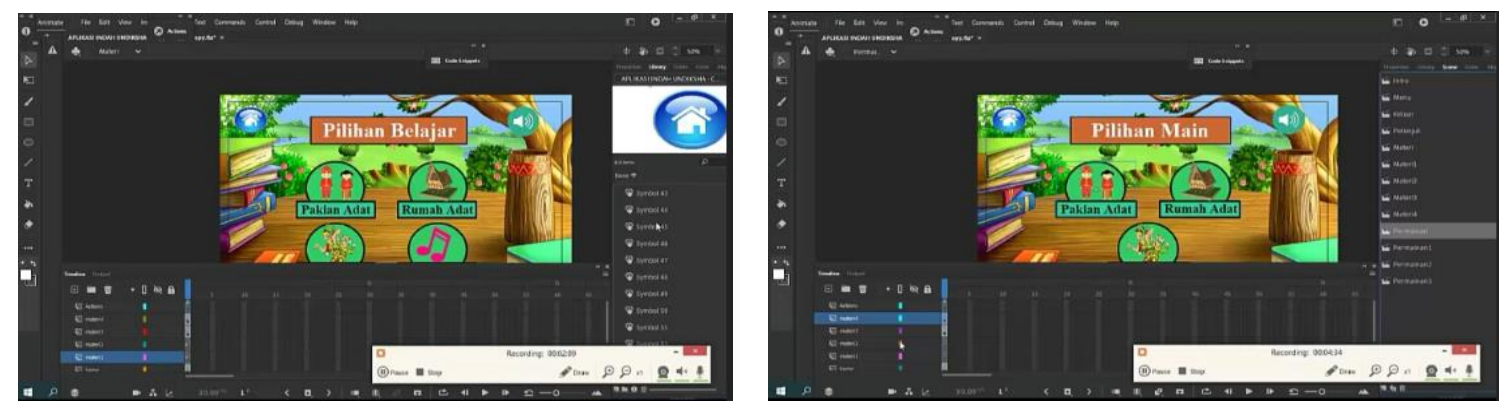

Gambar 2. Tahap Perancangan
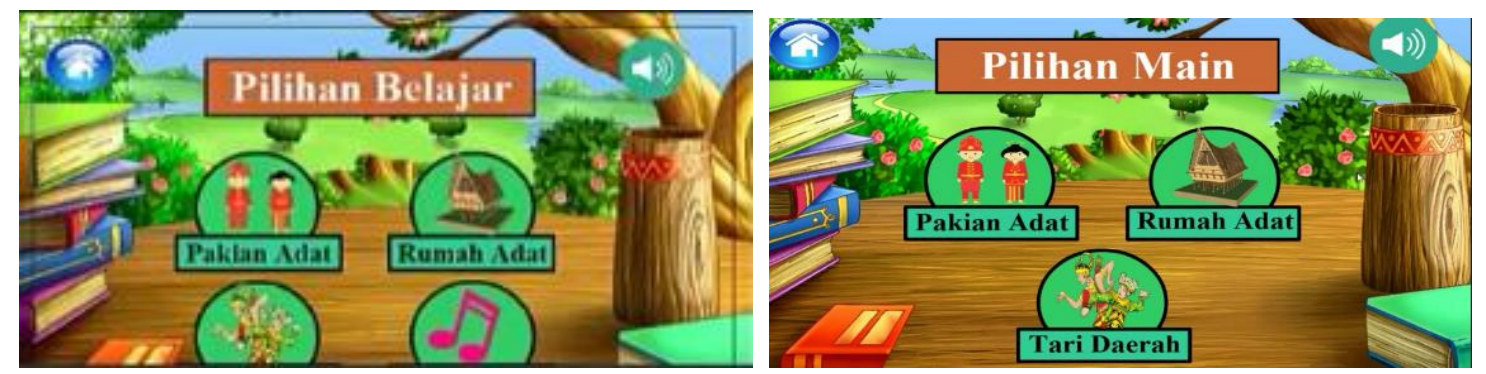

Gambar 3. Tahap Pengembangan

Hasil penilaian uji coba perorangan terhadap media pembelajaran berbasis audio visual ini dilakukan dengan menggunakan kuisioner yang diberikan kepada siswa. Berdsarkan hasil uji coba perorangan diperoleh nilai sebesar $88 \%$ berada pada rentangan $76-100 \%$ dengan kualifikasi sangat baik dengan tanpa revisi sehingga produk media pembelajaran ini tidak perlu direvisi.

Tabel 10. Hasil Perhitungan Uji Coba Perorangan

\begin{tabular}{|c|c|c|c|c|}
\hline \multirow{2}{*}{ No } & \multirow{2}{*}{ Aspek / Peryataan } & \multicolumn{3}{|c|}{ Responden } \\
\hline & & 1 & 2 & 3 \\
\hline 1 & Tampilan aplikasi sangat menarik & 4 & 3 & 4 \\
\hline 2 & $\begin{array}{l}\text { Huruf yang digunakan dalam aplikasi dapat dibaca oleh anak } \\
\text { dengan jelas }\end{array}$ & 3 & 4 & 4 \\
\hline 3 & Aplikasi mudah digunakan oleh anak & 3 & 4 & 3 \\
\hline 4 & $\begin{array}{l}\text { Penempatan materi dalam aplikasi dapat dibaca oleh anak } \\
\text { dengan jelas }\end{array}$ & 3 & 4 & 3 \\
\hline 5 & Ukuran huruf dalam aplikasi tidak terlalu kecil & 3 & 4 & 4 \\
\hline 6 & $\begin{array}{l}\text { Gambar dalam aplikasi sudah jelas dan sesuai dengan materi } \\
\text { yang disampaikan }\end{array}$ & 4 & 3 & 4 \\
\hline 7 & Aplikasi dapat membuat anak semangat belajar & 3 & 3 & 3 \\
\hline 8 & $\begin{array}{l}\text { Soal kuis pada aplikasi sudah sesuai dengan cerita yang ada } \\
\text { dalam aplikasi }\end{array}$ & 4 & 3 & 4 \\
\hline
\end{tabular}




\begin{tabular}{|c|c|c|c|c|}
\hline \multirow[b]{2}{*}{ No } & \multirow{2}{*}{ Aspek / Peryataan } & \multicolumn{3}{|c|}{ Responden } \\
\hline & & 1 & 2 & 3 \\
\hline 9 & Materi dalam aplikasi mudah dipahami oleh anak & 3 & 4 & 3 \\
\hline 10 & $\begin{array}{l}\text { Setelah menjawab soal pada kuis, diberikan balasan hasil } \\
\text { jawaban anak }\end{array}$ & 3 & 4 & 4 \\
\hline 11 & $\begin{array}{l}\text { Tujuan pembelajaran dalam aplikasi dapat anak pahami dengan } \\
\text { jelas }\end{array}$ & 4 & 3 & 4 \\
\hline \multirow{3}{*}{\multicolumn{2}{|c|}{$\begin{array}{l}\text { Jumlah skor } \\
\text { Skor Maksimal Ideal (SMI) } \\
\text { Presentase }\end{array}$}} & 37 & 39 & 40 \\
\hline & & & 44 & \\
\hline & & $84 \%$ & $\begin{array}{c}89 \% \\
264\end{array}$ & $91 \%$ \\
\hline
\end{tabular}

\section{Pembahasan}

Pengembangan media pembelajaran berbasis audio visual mengenai ayo belajar budaya nusantara ini dikembangkan dengan model pengembangan ADDIE yang terdiri dari 5 tahap yaitu (1) Tahap Analisis, (2) Tahap Perencanaan, (3) Tahap Pengembangan, (4) Tahap Implementasi, (5) Evaluasi. Model pengembangan ADDIE memiliki prosedur kerja yang mengacu pada tahapan Reseearch and Development (R\&D) namun lebih sistematik dan sederhana sehingga mampu menghasilkan produk yang lebih efektif.Perancangan media pembelajaran berbasis audio visual mengenai ayo belajar budaya nusantara ini diidentifikasi software yang tepat digunakan untuk merancang media yakni menggunakan software Adobe Flash CS6 atau Adobe Animate. Media ini dirancang semenarik mungkin dan dapat dengan mudah digunakan oleh anak untuk mengkreasi serta dapat menstimulasi perkembangan bahasa pada anak. Melalui penilain hasil uji ahli materi pembelajaran menyatakan bahwa media pembelajaran berbasis audio visual yang dikembangkan sudah sesuai.Pengembangan media pembelajaran berbasis audio visual mampu meningkatkan perkembangan bahasa pada anak usia dini, hal ini karena media pembelajaran dapat meningkatkan motivasi belajar anak. Media pembelajaran mampu meningkatkan focus dan semangat belajar siswa karena memiliki tampilan yang menarik seperti gambar, warna, dan animasi yang variatif (Krissandi \& Rusmawan, 2016; Miranda, 2019). Media pembelajaran berbasis audio visual dengan materi ayo belajar budaya nusantara memiliki kejelasan materi, kuis yang interaktif, tujuan pembelajaran yang jelas, dan tampilan yang menarik disukai oleh anak usia dini. Penggunaan media pembekalajaran sangat efektif sebagai media untuk mengembangkan semangat dan motivasi siswa, hal ini ditinjau melalui kriteria pembelajaran video untuk anak, yaitu syarat ideal media pembelajaran video harus memenuhi beberapa kriteria antara lain kejelasan pesan, berdiri sendiri, akrab dengan anak, representasi isi, visualisasi atau kualitas gambar baik dapat digunakan klaisikal maupun individual (Nurhayati et al., 2018). Media pembelajaran berbasis audio visual juga dapat menarik perhatian anak dalam proses pembelajaran (Nurdiyanti, 2019). Jadi media pembelajaran berbasis audio visual valid dan layak digunakan dalam proses pembelajaran serta mampu meningkatkan stimulus perkembangan bahasa pada anak usia dini dengan materi ayo belajar budaya nusantara.

Kelayakan media pembelajaran berbasis audio visual mengenai ayo belajar budaya nusantara juga dilihat dari segi media dan desain pembelajaran. Melalui penilaian hasil uji ahli media dan desain pembelajaran mendapatakan kualifikasi sangat baik karena media pembelajaran audio visual memiliki tampilan yang menarik, animasi yang variatif, dan warna yang bervariasi sehingga menarik perhatian anak untuk belajar. Dengan penggunaan media pembelajaran berbasis audio visual proses pembelajaran menjadi menyenangkan dan tidak membosankan. Pembelajaran yang baik adalah suatu proses kegiatan belajar yang mampu menciptakan kondisi yang positif bagi siswa dalam artian proses pembelajaran yang efektif dan menyenangkan serta mampu menumbuhkan motivasi siswa untuk belajar dalam mencapai hasil belajar yang optimal (Vadia et al., 2020). Hal serupa juga disampaikan oleh (Agustini \& Ngarti, 2020) bahwa video pembelajaran membawa dampak positif bagi kegiatan belajar peserta didik seperti demontrasi materi, motivasi, tutorial, dan efektivitas waktu. Pembelajaran dengan menggunakan media audio visual berkaitan denganindera penglihatan dan pendengaran sehingga dapat mengefektifkan kemampuan alat indera anak dan anak dengan mudah menangkap sebuah materi yang ditampilkan dalam media tersebut (Fitria, 2018).

Keefektifan media pembelajaran berbasis audio visual dapat dilihat dari hasil rerata uji coba perorangan sebesar $88 \%$. Hal ini dapat dikatakan bahwa media pembelajaran audio visual ayo belajar budaya nusantara mampu meningkatkan motivasi belajar anak dan menstimulus perkembangan bahasa pada anak. Hasil ini diperoleh karena dalam media pembelajaran berbasis audio visual terdapat materi pembelajaran budaya nusantara seperti pakaian adat dan rumah adat masing-masing daerah di Indonesia. Penggunaan media audiovisual berbasis budaya lokal pendidik telah mengenalkan pada anak usia dini secara bertahap dan berulang untuk menanamkan kecintaan terhadap budaya daerah. Media pembelajaran dikaitkan budaya yang sesuai dengan lingkungan anak, sehingga kreativitas guru berpengaruh pada 
pembelajaran (Darihastining et al., 2020; Sukma \& Evitriana, 2019). Hasil ini sesuai dengan beberapa penelitian yang menunjukkan bahwa penerapan audio visual tepat digunakan sebagai media pembelajaran (Amanda \& Putri, 2019; Naimah et al., 2019; Sulistiyarini et al., 2021). Dengan adanya media pembelajaran audio visual perkembangan bahasa pada anak menjadi meningkat. Audio visual pembelajaran memiliki kedudukan sebagai suplemen (tambahan) dalam proses pembelajaran (Hidayati et al., 2019). Media pembelajaran audio visual berbasis budaya nusantara dapat membuatperubahan positif pada anak dan meningkatkan ketertarikan anak untuk belajar dan tingkat pemahaman anak akan lebih tinggi.

\section{SIMPULAN}

Media pembelajaran audio visual ayo belajar budaya nusantara dalam upaya menstimulasi perkembangan bahasa pada anak ini dinyatakan layak digunakan pada anak usia dini, berdasarkan hasil uji validitas yang dilakukan oleh para pakar ahli dan uji coba perorangan kepada anak diperoleh kualifikasi sangat baik. Sehingga, media pembelajaran audio visual bisa digunakan sebagai salah satu alternatif media pembelajaran untuk anak usia dini.

\section{DAFTAR RUJUKAN}

Agustini, K., \& Ngarti, J. G. (2020). Pengembangan Video Pembelajaran Untuk Meningkatkan Motivasi Belajar Siswa Menggunakan Model R \& D. Jurnal Ilmiah Pendidikan Dan Pembelajaran, 4(April 2020), 62-78. https://doi.org/http://dx.doi.org/10.23887/jipp.v4i1.18403.

Amanda, D. A., \& Putri, A. R. (2019). Pengembangan Game Edukasi Pada Mata Pelajaran Matematika Materi Bangun Datar Berbasis Android di SDN 1 Jepun. JOEICT (Jurnal of Education and Information $\begin{array}{llll}\text { Communication } & \text { Technology), } & 3(2),\end{array}$ https://doi.org/https://doi.org/10.29100/joeict.v3i2.1241.

Anggraini, V., Yulsyofriend, Y., \& Yeni, I. (2019). Stimulasi Perkembangan Bahasa Anak Usia Dini Melalui Lagu Kreasi Minangkabau Pada Anak Usia Dini. Pedagogi : Jurnal Anak Usia Dini Dan Pendidikan Anak Usia Dini, 5(2), 73. https://doi.org/10.30651/pedagogi.v5i2.3377.

Cahya Ningrum, E. S., Christianti, M., Maryatun, I. B., \& Cholimah, N. (2020). Pelatihan penggunaan buku panduan pembuatan dan pelaksanaan pembelajaran di taman lalu lintas untuk guru taman kanakkanak. Jurnal Pendidikan Anak, 9(1), 1-8. https://doi.org/10.21831/jpa.v9i1.31395.

Darihastining, S., Aini, S. N., Maisaroh, S., \& Mayasari, D. (2020). Penggunaan Media Audio Visual Berbasis Kearifan Budaya Lokal pada Anak Usia Dini. Jurnal Obsesi : Jurnal Pendidikan Anak Usia Dini, 5(2), 1594-1602. https://doi.org/10.31004/obsesi.v5i2.923.

Darmayanti, P., Tegeh, I. M., \& Ujianti, R. (2017). Efektivitas Metode Bercerita Dengan Media Boneka Wayang Terhadap Kemampuan Bercakap-Cakap Anak Kelompok B Di Tk Widya Sesana Sangsit 2016/2017. E-Journal Pendidikan Anak Usia Dini Universitas Pendidikan Ganesha Jurusan Pendidikan Guru $\begin{array}{llll}\text { Pendidikan Anak Usia } & \text { Bni, 336-347. }\end{array}$ https://doi.org/http://dx.doi.org/10.23887/paud.v5i1.11557.

Fatihakun, A., \& Suryadilaga, M. A. (2021). Urgensi Pendidikan Anak Usia Dini Dalam Perspektif Hadits di Masa Pandemi Coronavirus. 3(1). https://doi.org/https://doi.org/10.15642/jeced.v3i1.601.

Fatihakun, A., Wahidah, N., \& Latipah, E. (2021). Pentingnya Mengetahui Perkembangan Bahasa Anak Usia Dini. Pendidikan Raudhatul Athfal, https://doi.org/https://doi.org/10.15575/japra.v4i1.10940.

Fatmawati, Sukartiningsih, W., \& Indarti, T. (2021). Media Pembelajaran Audio Visual: Literature Review. Pionir: Jurnal Pendidikan, 10(1), 6.

Fitria, A. (2018). Penggunaan Media Audio Visual Dalam Pembelajaran Anak Usia Dini. Cakrawala Dini: Jurnal Pendidikan Anak Usia Dini, 5(2), 57-62. https://doi.org/10.17509/cd.v5i2.10498.

Hidayati, A., Adi, E., \& Praherdhiono, H. (2019). Bangan Media Video Pembelajaran Untuk Meningkatkan Pemahaman Materi Gaya Kelas Iv Di Sdn Sukoiber 1 Jombang. JINOTEP (Jurnal Inovasi Dan Teknologi Pembelajaran) Kajian Dan Riset Dalam Teknologi Pembelajaran, 6(1), 45-50. https: //doi.org/10.17977/um031v6i12019p045.

Krissandi, A. D. S., \& Rusmawan. (2016). Kendala Guru Sekolah Dasar Dalam Implementasi Kurikulum 2013 Apri. Cakrawala Pendidikan, 457-467. https: //doi.org/https://doi.org/10.21831/cp.v3i3.7409.

Maqfiroh, D. N. M., Khutobah, K., \& Budyawati, L. P. I. (2020). Pengembangan Media Motif (Monopoli Edukatif) Dalam Pembelajaran Berbasis Multiple Intelligence Pada Anak Tk Kelompok B. Cakrawala Dini: Jurnal Pendidikan Anak Usia Dini, 11(1), 65-74. https://doi.org/10.17509/cd.v11i1.24230.

Miranda, D. (2019). Pengembangan Video Animasi Berbasis Karakter Cinta Tanah Air Untuk Anak Usia Dini. 
Jurnal Visi Ilmu Pendidikan, 11(2), 12. https://doi.org/10.26418/jvip.v11i2.32565.

Naimah, J., Winarni, D. S., \& Widiyawati, Y. (2019). Pengembangan Game Edukasi Science Adventure Untuk Meningkatkan Keterampilanpemecahan Masalah Siswa. Jurnal Pendidikan Sains Indonesia (Indonesian Journal of Science Education), 7(2), 91-100. https://doi.org/10.24815/jpsi.v7i2.14462.

Najmina, N. (2018). Pendidikan Multikultural Dalam Membentuk Karakter Bangsa Indonesia. Jupiis: Jurnal $\begin{array}{llll}\text { Pendidikan } \quad \text { Ilmu-Ilmu } & \text { Sosial, }\end{array}$ https://doi.org/https://doi.org/10.24114/jupiis.v10i1.8389.g9059.

Nurdiyanti, S. (2019). Implementasi Media Visual Dan Audiovisual Terhadap Pembelajaran Anak Usia Dini Di Era Revolusi Industri 4 . 0. Universitas Sultan Ageng Tirtayasa, 2(1), 642-650.

Nurhayati, I., Khumaedi, M., \& Yudiono, H. (2018). The Effectiveness of the Use of Video Media on Learning on the Competence of Scalp and Hair Care of Vocational High School Students of Beauty Department. Journal of Vocational and Career Education, 3(1), 66-72. https://doi.org/10.15294/jvce.v3i1.15388.

Patmawati, D., Ws, R., \& Halimah, M. (2018). Pengaruh Media Audio Visual Terhadap Hasil Belajar Siswa Pada Materi Jenis-Jenis Pekerjaan Di Sekolah Dasar. PEDADIDAKTIKA: Jurnal Ilmiah Pendidikan Guru Sekolah Dasar, 5(2), 308-316.

Pradnyana, I. K. A., Pradnyana, I. M. A., \& Suyasa, P. W. A. (2020). Pengembangan Multimedia Pembelajaran Interaktif PPKN untuk Siswa Tunagrahita dengan Konsep Gamifikasi. Pendidikan Teknologi Dan Kejuruan, 17(2), 166-176. https://doi.org/http://dx.doi.org/10.23887/jptk-undiksha.v17i2.

Santyasa, I. W., Warpala, I. W. S., \& Sudarma, I. K. (2018). The Power of Group Investigation Model on Student Critical Thinking, Attitude, and Character in Learning Physics. 274, 101-106. https://doi.org/10.2991/iccite-18.2018.23.

Setiawan, A., Praherdhiono, H., \& Suthoni, S. (2019). Penggunaan Game Edukasi Digital Sebagai Sarana Pembelajaran Anak Usia Dini. JINOTEP (Jurnal Inovasi Dan Teknologi Pembelajaran) Kajian Dan Riset Dalam Teknologi Pembelajaran, 6(1), 39-44. https://doi.org/10.17977/um031v6i12019p039.

Subandji, Shofa, M. F., \& Syamsiyati, R. N. (2020). Analisis kompetensi pendidik PAUD pada alumni program studi PIAUD FIT IAIN Surakarta. Jurnal Pendidikan Anak, 9(1), 9-19. https://doi.org/https://doi.org/10.21831/jpa.v9i1.30651.

Sukma, H. H., \& Evitriana, N. (2019). Pengembangan Media Audio Visual Sebagai Media Pembelajaran Menyimak Komprehensif Berbasis Budaya Nusantara untuk Kelas III Sekolah Dasar. Seminar Nasional Pagelaran Pendidikan Dasar Nasional (PPDN), 408-416.

Sulistiyarini, D., Ramadhani, D., \& Sabirin, F. (2021). Developing Serious Video Games for Data Communication Courses. Jurnal Teknologi Pendidikan, 23(April), 11-22. https://doi.org/http://dx.doi.org/10.21009/JTP2001.6.

Susila, I. M. O., Darmawiguna, I. G. M., \& Sindu, I. G. P. (2018). Pengembangan Game Edukasi Nihongo Benkyou Berbasis Android. Kumpulan Artikel Mahasiswa Pendidikan Teknik Informatika (KARMAPATI), 7(2), 76. https://doi.org/10.23887/karmapati.v7i2.15275.

Syukur, A., \& Fallo, Y. T. (2019). Peningkatan Kemampuan Anak dalam Mengenal Konsep Bilangan Melalui Penggunaan Media Pembelajaran Berbasis Alam. Jurnal PG-PAUD Trunojoyo :Jurnal Pendidikan Dan Pembelajaran Anak Usia Dini, 6(1), 1-11. https://doi.org/10.21107/pgpaudtrunojoyo.v6i1.5365.

Tuasikal, P. (2021). Peran Pendidikan Multiculturalisme Dalam Mencegah Culture di era pandemic covid 19. $02(1), 42-49$

Vadia, P., Riandini, A., Sudatha, I. G. W., \& Parmiti, D. P. (2020). Korelasi antara Kecerdasan Emosional dan Motivasi Belajar dengan Hasil Belajar PPKn. Jurnal Mimbar PGSD Undiksha, 8(3), 468-478. https://doi.org/http://dx.doi.org/10.23887/jjpgsd.v8i3.26072.

Yuangga, K. D., \& Sunarsi, D. (2020). Pengembangan Media Dan Strategi Pembelajaran Untuk Mengatasi Permasalahan Pembelajaran Jarak Jauh Di Pandemi Covid- 19. Jurnal Guru Kita, 4(3), 51-58. https://doi.org/https://doi.org/10.24114/jgk.v4i3.19472.

Zeptyani, P. A. D., \& Wiarta, I. W. (2020). Pengaruh Project-Based Outdoor Learning Activity Menggunakan Media Audio Visual Terhadap Perilaku Belajar Anak Usia Dini. Jurnal Pendidikan Anak Usia Dini Undiksha, 8(2), 69-79. https://doi.org/http://dx.doi.org/10.23887/paud.v8i2.24740. 